\title{
Mixed first and second division restitution in male meiosis of Hierochloë odorata (L.) Beauv (Holy Grass)
}

\author{
COLIN FERRIS, ROBERT S. CALLOW* \& ALAN J. GRAY† \\ Department of Biological Sciences, University of East Anglia, University Plain, Norwich NR4 7TJ, *Plant Science and \\ Cytogenetics Group, Department of Cell and Structural Biology, Williamson Building, The University, Manchester \\ M13 9PL, and IInstitute of Terrestrial Ecology, Furzebrook Research Station, Wareham, Dorset BH20 5AS, U.K.
}

\begin{abstract}
Hierochloë odorata is a rhizomatous perennial grass of northern latitudes with a highly restricted distribution in Britain and Ireland. Six clones sampled from Scotland are tetraploid $(2 n=4 x=28)$ and most show irregular male meiosis, characterized by the exclusion of laggards as micronuclei, and are probably pseudogamous. In both these respects they resemble $H$. odorata from Swedish Lapland which is octaploid $(2 n=8 x=56)$. Material from one Scottish locality shows meiotic restitution in the majority of its pollen mother cells ( 77 per cent $)$. One in two first divisions leads to restitution ( 52 per cent) and one in seven of these ( 14 per cent) remains undivided even at telophase-II. Of those dyads formed from normal first division, almost half ( 46 per cent) show failure of one of the second divisions but only one in 20 shows double second division failure. This remarkable mixture of first and second division restitution is reflected in an extensive range of ploidy $(n=2 x, 4 x$, $8 x$ ) and pollen grain size $\left(35-113 \mu \mathrm{m}^{3}\right)$. Seed-set in this material is low (2 per cent). Genetic variation in British material is revealed by isozyme electrophoresis while studies of total seed proteins in Swedish material indicate genetic uniformity. Implications for parthenogenesis are discussed.
\end{abstract}

Keywords: clonal reproduction, Hierochloë, isozymes, meiotic restitution, parthenogenesis, polyploidy.

\section{Introduction}

Restitution occurs when a cell fails to divide despite replication of the chromosomes, thus resulting in a doubling of the chromosome number usually present in that type of cell (Rosenberg, 1926). Such a mechanism is essential to parthenogenesis. Mitotic restitution may occur just prior to meiosis as in the grasshopper Warramaba virgo (White, 1970) or by post-meiotic doubling which leads to instant total homozygosity as seen in whiteflies, Aleyrodidae (John \& Lewis, 1975). Restitution during meiosis leads to the production of unreduced or polyploid gametes. Conversely, unreduced gametes have been used as evidence of restitution in many species including red clover (Parrot \& Smith, 1984), Trillium spp. (Stern, 1946) and potato (Fukuda, 1927). Parthenogenesis affects many genera as shown by reports of unreduced gamete formation (Harlan \& De Wet, 1975; Cuellar, 1987).

First division failure has been reported in many species including potatoes (Ramanna, 1983) and meadow grasses (Müntzing, 1940). It may reflect nondisjunction at the first division (Wagenaar, 1968) or abberant spindles during the second division causing the products of the first division to be reunited. Spindle aberrations may be caused by second division spindles lying next to each other (Mok \& Peloquin, 1975a), by tripolar spindles (Veilleux et al., 1982) or by the fusion of the second division spindles to form one large spindle (Ramanna, 1979). All three types have been found in potato (Veilleux et al., 1982).

Second division restitution is less common than first but has been reported in several plants including species of Datura (Satina \& Blakeslee, 1934) and some orchids (Teoh, 1984). It can arise when cytokinesis occurs prematurely such that the second meiotic division does not occur. This has been observed in potato (Mok \& Peloquin, 1975a). Such failure may affect one or both of the second divisions and has been attributed to recessive genes such as elongate in maize 
(Rhoades \& Dempsey, 1966), dyad in Datura (Satina \& Blakeslee, 1934) and the restitution pollen gene in alfalfa (McCoy, 1982).

Hierochloë odorata is a grass with an arctic/subarctic distribution and is highly restricted in Britain. The present study forms part of an investigation of genetic variation in a species of restricted distribution using cytological and electrophoretic techniques. In some Arctic/alpine grasses, such as Poa alpina (Müntzing, 1940; MacEwan, 1986) and Hierochloë alpina (Weimarck, 1976), parthenogenesis is accompanied by extensive aneuploidy. By contrast, $H$. odorata shows variation in ploidy but no sign of aneuploidy. While an understanding of the mechanisms of parthenogenesis requires the study of female meiosis, we can look at male meiosis for evidence of meiotic breakdown (Cuellar, 1987).

The material in this study is referred to as Hierochloe odorata, sensu lato. The tetraploid most closely resembles $H$. odorata spp. odorata while the octaploid best fits the description of $H$. hirta spp. arctica as given by Weimarck (1971).

\section{Materials and methods}

Flowering tillers of Hierochloë odorata were collected from Scotland and Swedish Lapland. Root tips for

(a)

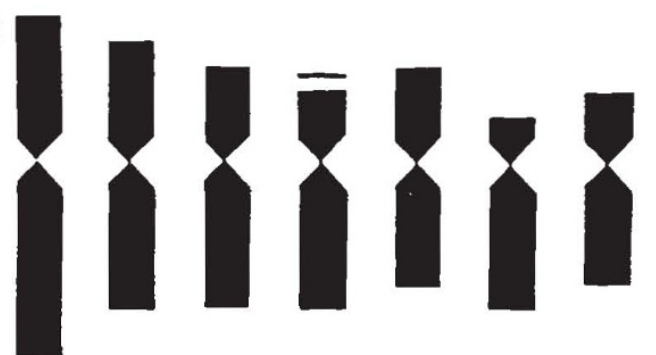

(b)

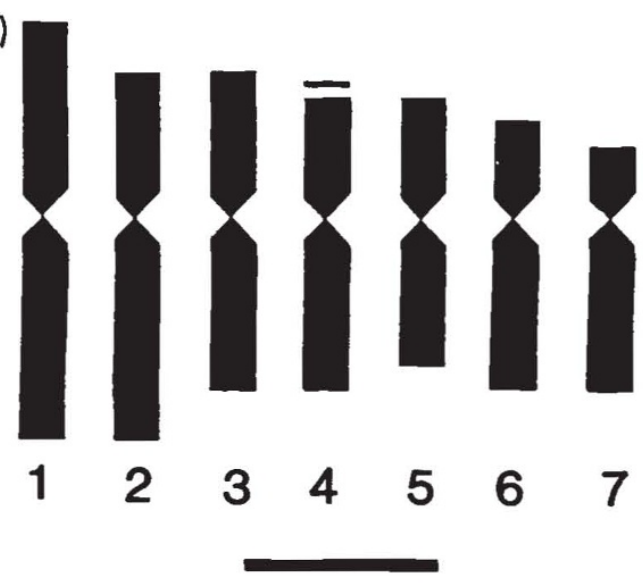

Fig. 1 Karyotype idiograms of Hierochloë odorata (a) octaploid $2 n=8 x=56$; (b) tetraploid $2 n=4 x=28$. Bar represents $2 \mu \mathrm{m}$. mitotic preparations were pretreated in colchicine $(0.05)$ per cent) for $5 \mathrm{~h}$ and fixed in ethanol: acetic acid $(3: 1)$ for at least $24 \mathrm{~h}$ at $5^{\circ} \mathrm{C}$. Fixed material was hydrolysed in $1 \mathrm{M} \mathrm{HCl}$ at $60^{\circ} \mathrm{C}$ for $6 \mathrm{~min}$, stained in feulgen and tapped out in lacto-propionic orcein. Inflorescences were fixed as above for meiotic analysis of pollen mother cells (PMCs), single anthers being tapped out in lacto-propionic orcein (Dyer, 1963). Isoenzymes of phosphoglucose isomerase and esterase were analysed using horizontal starch gel electrophoresis. Leaf samples were crushed in a $0.05 \mathrm{M}$ citrate buffer ( $\mathrm{pH} \mathrm{8.3)}$ and applied to starch gels (12 per cent) on paper wicks. Gels were run in a $0.2 \mathrm{M}$ borate buffer ( $\mathrm{pH} \mathrm{8.3)} \mathrm{for} 25 \mathrm{~min}$ at $35 \mathrm{~mA}, 140 \mathrm{~V}$; the wicks were removed and the gels run for a further $4 \mathrm{~h}$ at $50 \mathrm{~mA}, 150 \mathrm{~V}$. Sodium dodecyl sulphate polyacrylamide gel electrophoresis was used for seed protein analysis. Seeds were crushed in a $0.125 \mathrm{~m}$ borate extraction buffer $(\mathrm{pH} 8.9$ ) containing mercaptoethanol and polyvinyl pyrrolidone, and were applied to wells on polyacrylamide gels ( 7.5 per cent). Gels were run in vertical bed apparatus in a $0.5 \mathrm{M} \mathrm{HCl}$ buffer $(\mathrm{pH} 6.8)$ at $50 \mathrm{~mA}, 150 \mathrm{~V}$ and stained in coomassie blue for $1.5 \mathrm{~h}$.

\section{Results}

\section{Mitotic complements}

Karyotypes of Hierochloë odorata from six Scottish clones and from two Swedish populations were examined (Fig. 1). Scottish plants were all tetraploid with 28 chromosomes ranging in length from 2.5 to $4.3 \mu \mathrm{m}$. Up to four distal nucleolar organizing regions (NORs) were seen on the short arm of chromosome four (Fig. 2a). By contrast, 20 plants from each Swedish population were all octaploid with 56 chromosomes ranging in length from 2.0 to $3.5 \mu \mathrm{m}$ (Fig. 2b). The NORs again were located distally on the short arm of chromosome four, although no more than three were seen in a single cell.

\section{Male meiosis in tetraploids}

Pachytene nuclei displayed a high degree of pairing, including occasional synaptic exchanges (Fig. 3a). At metaphase-I, the 28 chromosomes were organized into 14 bivalents (Fig. $3 \mathrm{~b}$ ) in 85 per cent of cells. Pairs of univalents occurred in 10 per cent of cells while the remaining 5 per cent contained one, rarely two, multivalents. Adjacent and alternate ring and chain quadrivalents were seen. Trivalents were all convergent except for one saucepan trivalent. Numbers of chiasmata ranged from 25 to at least 35 per cell but the possibility of differences between clones was not assessed. 

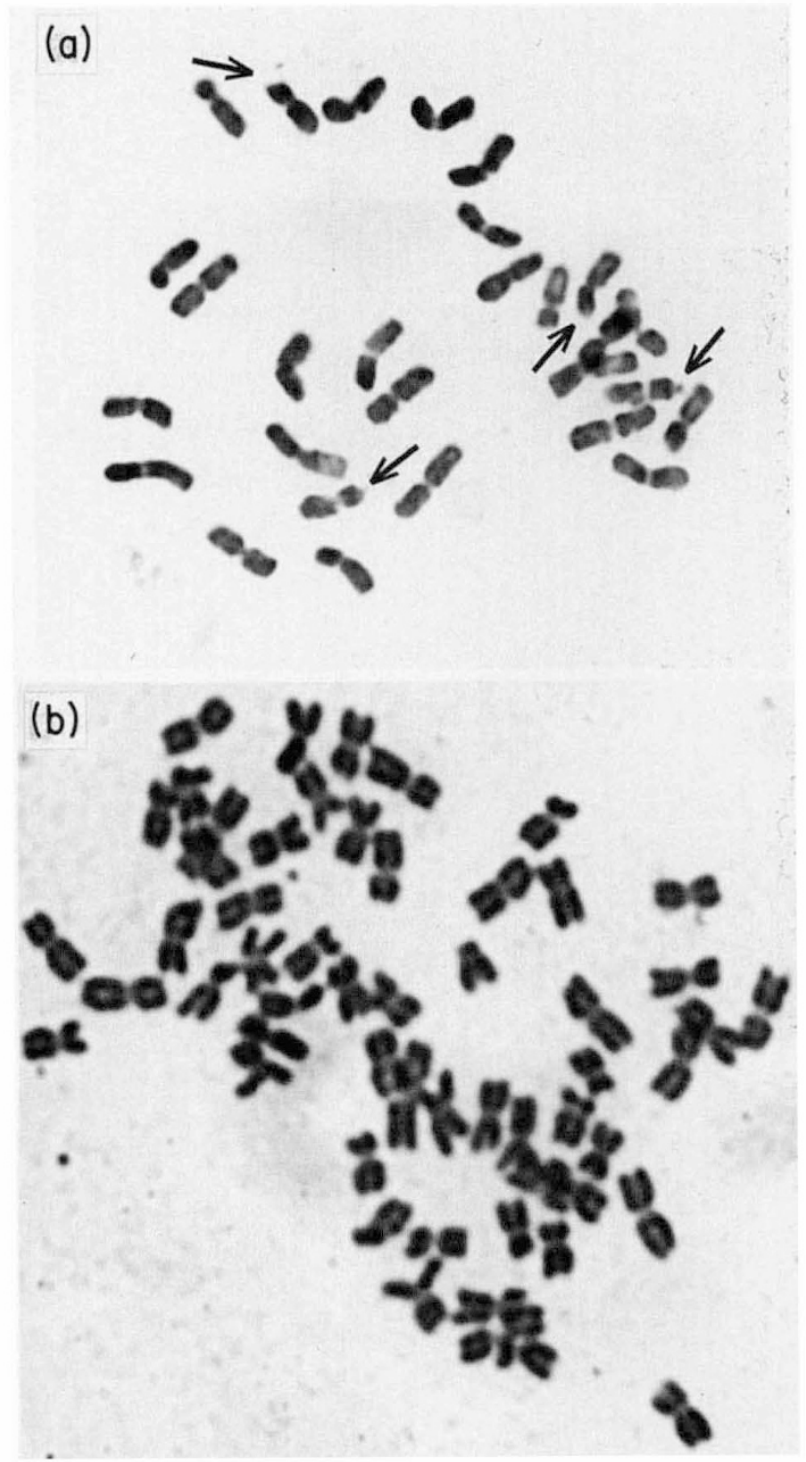

Fig. 2 Standard karyotypes of Hierochloë odorata. (a) Scottish tetraploid complement $2 n=4 x=28$, with nucleolar organizing chromosomes (arrowed); (b) Swedish octaploid complement $2 n=8 x=56$. Bar represents $10 \mu \mathrm{m}$.

In all plants examined, laggards were seen in some anaphase-I PMCs (Fig. 3c). Bridges and acentric fragments occurred in 2 per cent of anaphase-I PMCs from the Ravenshall clone (Fig. 3d, e). In five of the clones investigated telophase-I and telophase-II indicated normal division with production of dyads and tetrads respectively. In the Ravenshall clone, however, all PMCs at telophase-I lacked the first division cell plate. Of these PMCs 52 per cent were monads, resulting from first division restitution (Fig. 3f). Telophase-II PMCs all contained their second division cell plate but lacked the first division plate. Five categories of PMC were observed: intermingled within each anther (Fig. 4) but displaying a range of frequencies (Fig. 5). Tetrads represented 23.4 per cent of PMCs, while 22 per cent were triads and 7.2 per cent monads (Fig. $3 \mathrm{i}-\mathrm{k}$ ). The remaining PMCs were dyads but could be separated into two classes. The cell plate separates the two nuclei in 94.5 per cent of dyads (Fig. 3h) while in 5.5 per cent both of the restitution nuclei were seen to interrupt the cell plate (Fig. $3 \mathrm{~g}$ ). These two kinds of second division dyad will be referred to as types I and II respectively.

Telophase-II in other clones revealed extensive production of micronuclei in up to 10 per cent of PMCs (Fig. 6a). A maximum of four micronuclei was seen in any microspore (Fig. 6b). Within a single clone, the frequency distribution of micronuclei per microspore did not fit the Poisson distribution but rather was slightly but significantly contagious $\left(\chi_{\mid 1\}}^{2}=62.479, P<0.001\right)$ (Table 1a). Such non-randomness seems to be largely attributable to the non-random distribution of micronucleate microspores amongst tetrads, cases of a single micronucleate spore within a tetrad occurring at less than half their expected frequency (Table 1b). Pollen grain diameter exhibited a limited range $(19-25 \mu \mathrm{m})$ in five Scottish clones but was more variable in the Ravenshall clone $(19-30 \mu \mathrm{m})$ (Fig. $6 \mathrm{c})$, due to the presence of a few giant grains (Fig. 7).

\section{Male meiosis in octaploids}

Although metaphase-I has been observed in octaploid plants, it is not amenable to analysis (Fig. 6d). Univalents appear to be frequent and some multivalents may also be present. Bridges and fragments occurred sporadically at anaphase-I (Fig. 6e) but laggards were common at this stage (Fig. 6f). Telophase-I and telophase-II showed no evidence of restitution but micronuclei were observed in about 80 per cent of microspores (Fig. 6g, h) (Table 2). Within a single clone, the incidence of micronuclei conformed to a Poisson distribution at telophase-I but displayed evidence of slight uniformity by telophase-II (Table 2 ).

\section{Enzymic variation}

Electrophoresis on esterase in seed progeny of Scottish tetraploids revealed variation between half-sibs. Of six half-sibs from Ravenshall, four were heterozygous for esterase 2 and two were homozygous for the slow allele. Four out of five half-sibs from Southwick were homozygous for the slow allele while one plant was heterozygous. Two alleles for PGI were found and plants were either heterozygous or homozygous for the fast allele. Four Mary's Knowe half-sibs were all heterozygotes while two of three Ravenshall half-sibs and one of four Southwick half-sibs were homozygotes for the fast allele. 
(a)

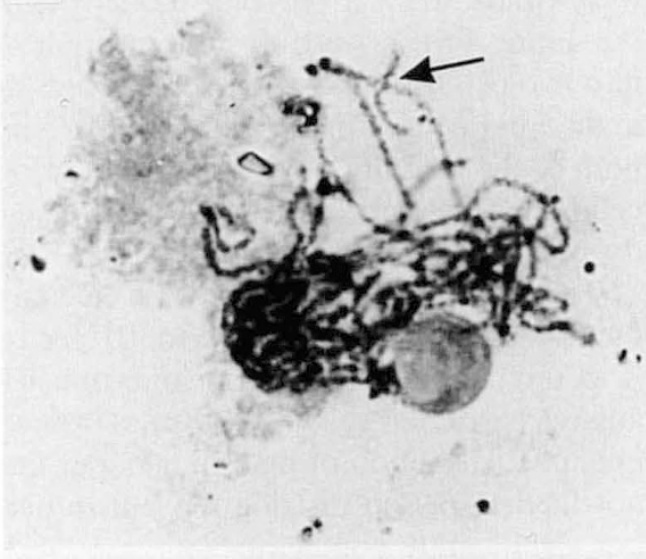

(b)

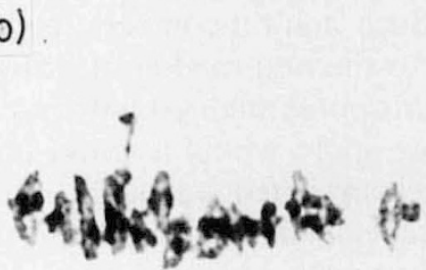

(c)

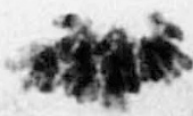

(f)

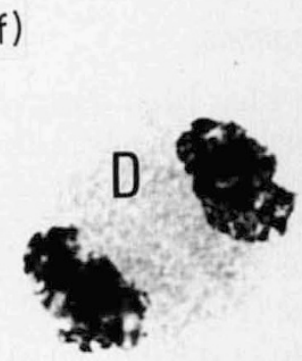

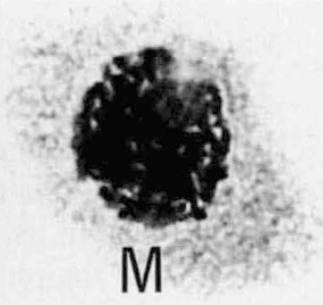

(g)
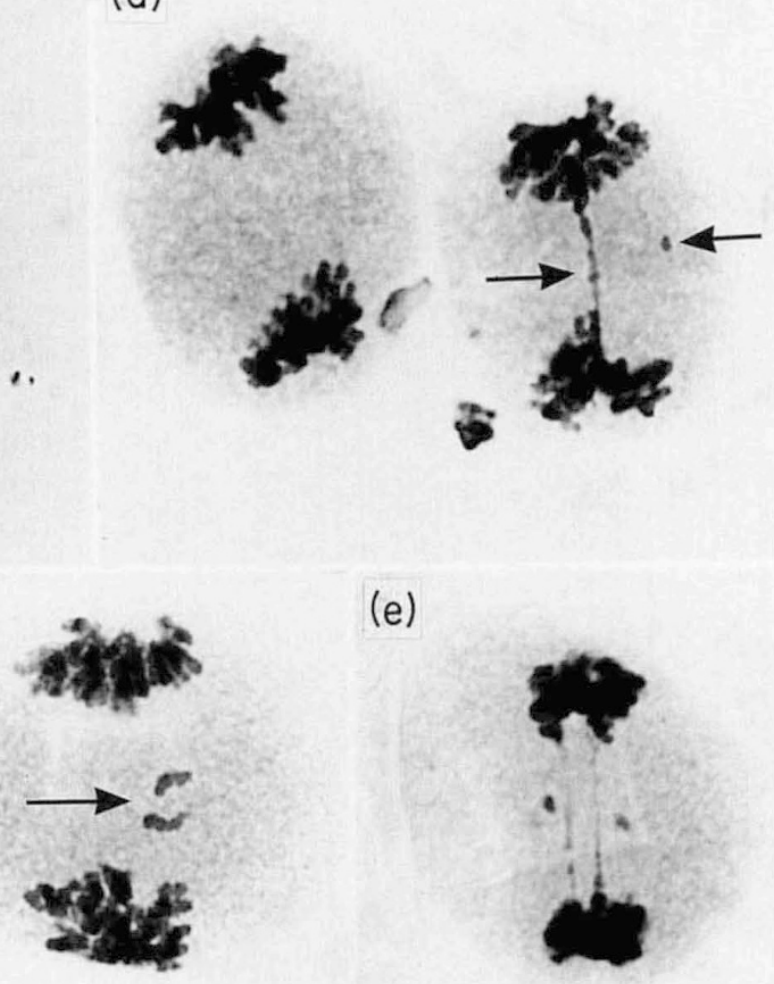

(e)

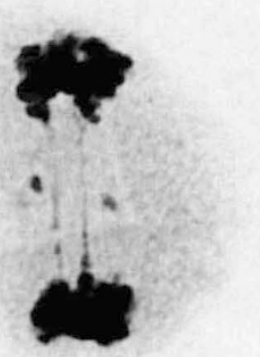

(h)
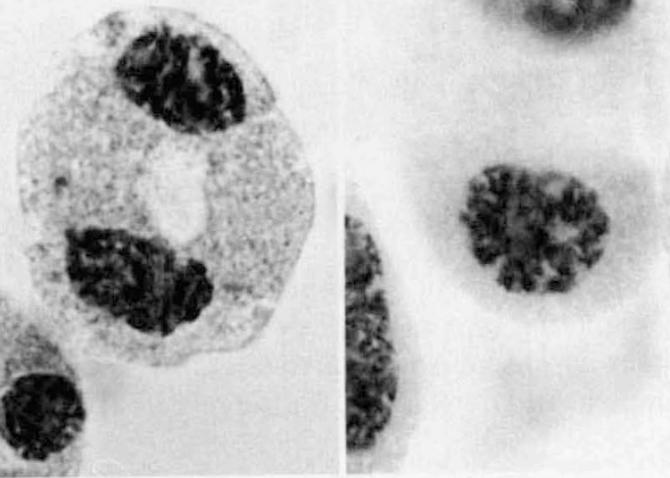

(i)

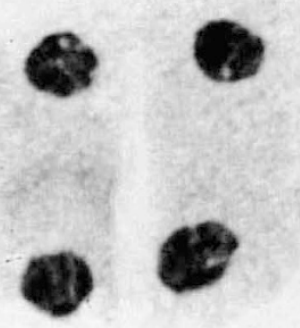

(j)

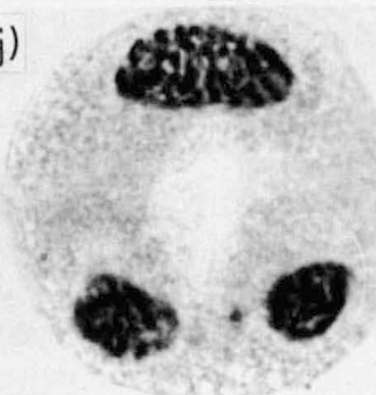

(k)

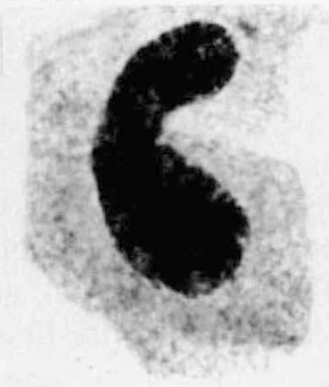

Fig. 3 Meiosis in tetraploid Hierochloë odorata from Ravenshall Point. (a) Pachytene with pairing partner exchange (arrowed); (b) metaphase-I; (c) anaphase-I with laggard univalents (arrowed); (d) anaphase-I showing formation of bridge and fragment (arrowed); (e) anaphase-I showing double bridge and fragment formation; (f) telophase-I with first division dyads (D) and restitution monads (M), (g-k) Telophase-II, (g) second division restitution (SDR) dyad; (h) first division restitution (FDR) dyad; (i) tetrad; (j) SDR triad; (k) monad from successive FDR and SDR. Bar represents $10 \mu \mathrm{m}$. 

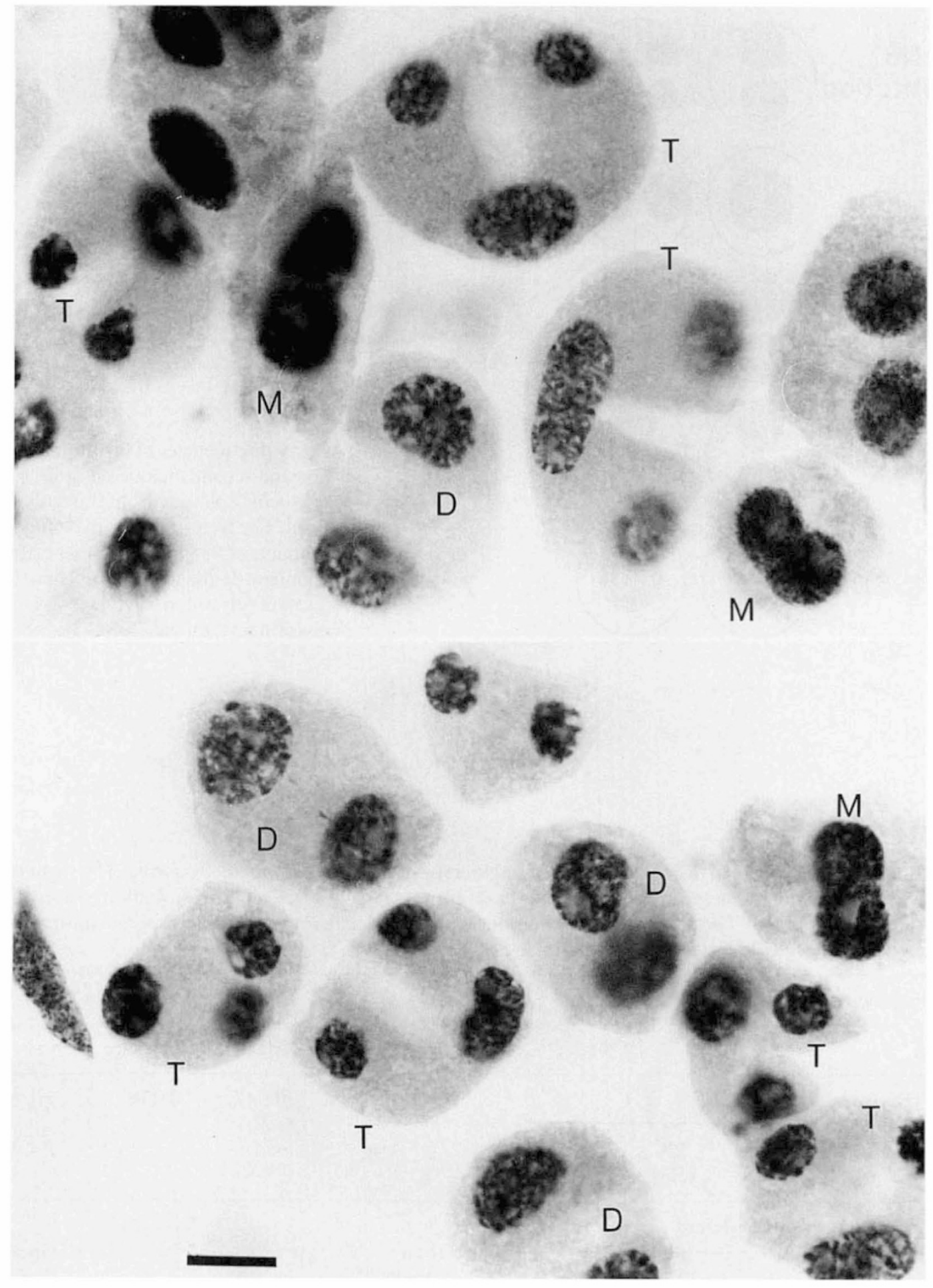

Fig. 4 Products at telophase-II of mixed first and second division restitution in Hierochloë odorata from Ravenshall Point. (M) monad, (D) dyad, (T) triad. Bar represents $10 \mu \mathrm{m}$. 
(a)

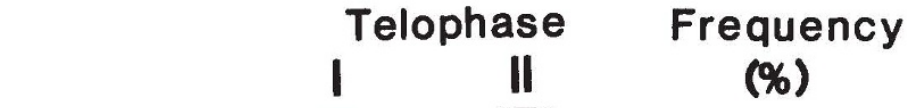

(b)

FDR

(c) SDR

(d)

$$
\begin{aligned}
& \text { Double } \\
& \text { SDR }
\end{aligned}
$$

(e) FDR \& SDR
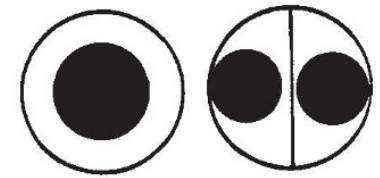

\author{
44.8
}

22.0

2.6

7.2

Fig. 5 Frequencies of restitution at the first and second meiotic divisions in Hierochloë odorata from Ravenshall Point. The frequencies of the different products of 928 pollen mother cells at telophase-II are given. (FDR) first division restitution (SDR) second division restitution.

Table 1 Incidence of micronuclei in microspores from a single clone of tetraploid Hierochloë odorata. The slight but very highly significant deviation from randomness amongst microspores (a) appears largely to reflect the distribution of micronucleate microspores amongst tetrads $(\mathrm{b})$. The proportions of micronucleate $(p)$ and amicronucleate microspores $(q)$ were estimated from the data. Expected frequencies are given in parentheses.

\begin{tabular}{|c|c|c|c|c|c|c|c|c|c|}
\hline 0 & 1 & 2 & 3 & 4 & $>4$ & $\begin{array}{l}\text { Total } \\
\text { microspores }\end{array}$ & Mean & Variance & $\begin{array}{l}\text { Goodness of fit } \\
\text { to Poisson }\end{array}$ \\
\hline 4813 & 188 & 20 & 2 & 1 & 过 & 5024 & 0.047 & 0.056 & $\chi_{[1]}^{2}=62.479$ \\
\hline$(4791.5)$ & $(227.0)$ & & & & & & & & $P<0.001$ \\
\hline
\end{tabular}

(a) Micronuclei/microspore

\begin{tabular}{|c|c|c|c|c|c|c|c|c|}
\hline 0 & 1 & 2 & 3 & 4 & $\begin{array}{l}\text { Total } \\
\text { tetrads }\end{array}$ & $p$ & $q$ & $\begin{array}{l}\text { Goodness to fit to } \\
\text { the binomial }(p+q)^{4}\end{array}$ \\
\hline 1119 & 82 & $\underbrace{38}$ & 15 & 2 & 1256 & 0.042 & 0.958 & $\chi_{[1]}^{2}=203.956$ \\
\hline$(1057.9)$ & $(185.5)$ & & $\begin{array}{c}55 \\
(12.6)\end{array}$ & & & & & $P<0.001$ \\
\hline
\end{tabular}

(b) Microspores with micronuclei/tetrad 
(a)
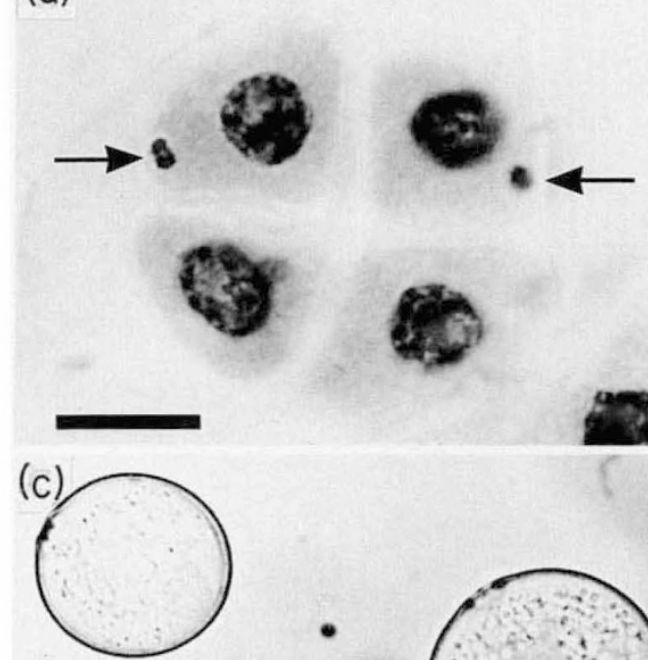

(e)

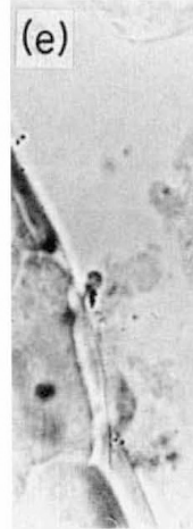

(g)

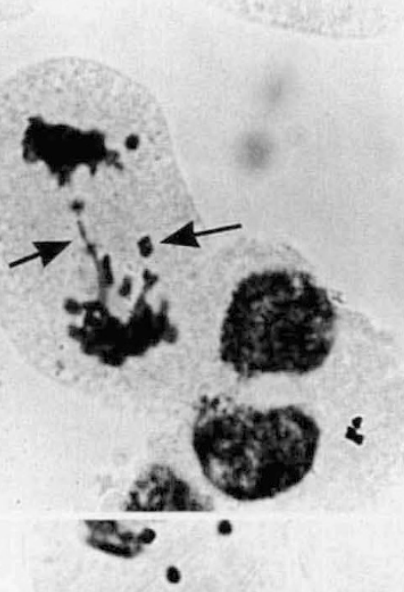

(b)

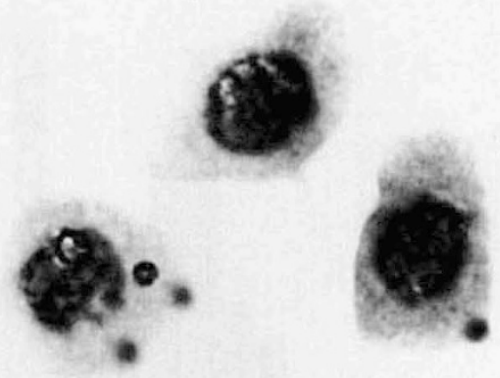

(d)

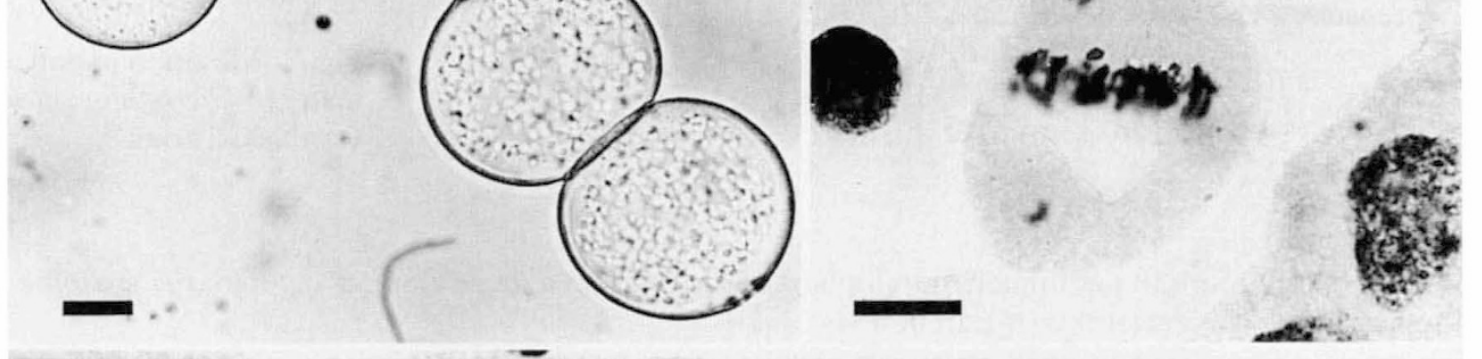

(f)

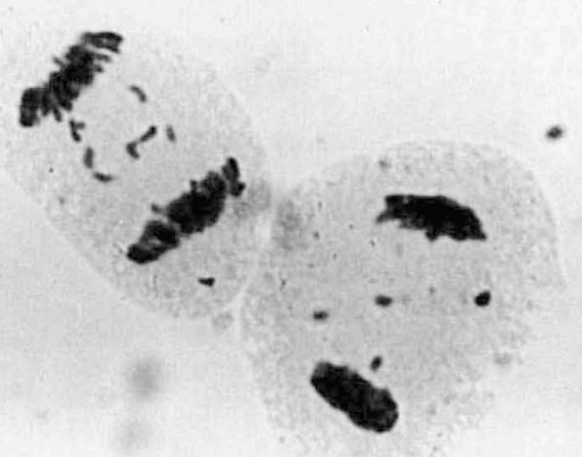

(h)

$-47$

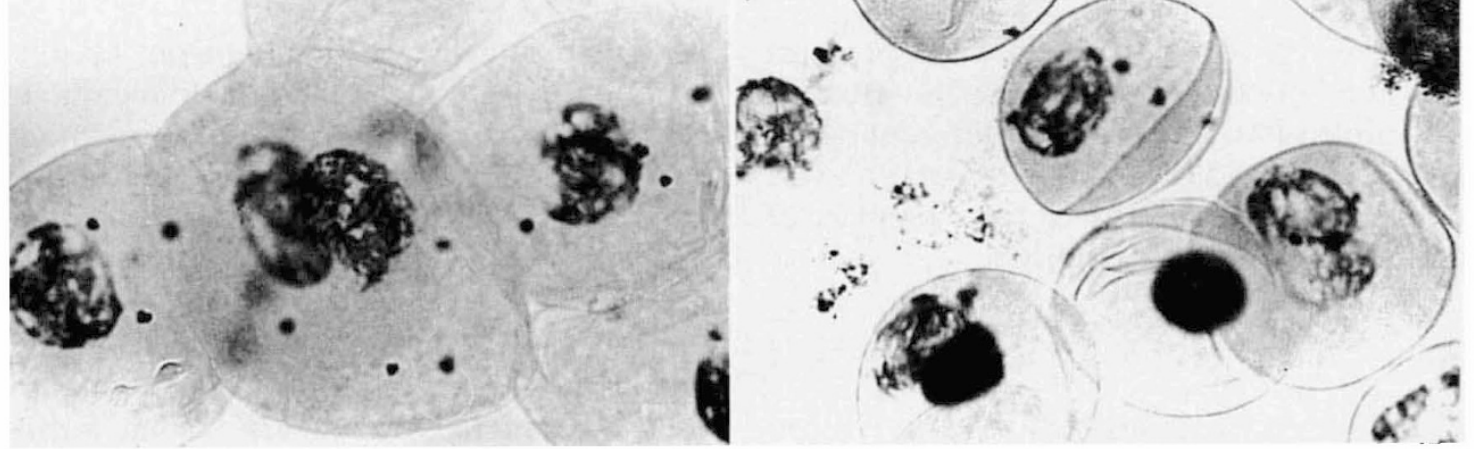

Fig. 6 Meiosis in Hierochloë odorata, (a-c) Tetraploid $2 n=4 x=28$; (d-h) octaploid $2 n=8 x=56$. (a) Telophase-II tetrad showing micronuclei (arrowed); (b) telophase-II microspores with up to four micronuclei; (c) variation in pollen grain size in the Ravenshall clone; (d) metaphase-I showing univalents; (e) anaphase-I with bridge and fragment (arrowed); (f) anaphase-I with laggard univalents; (g) telophase-I with micronuclei; (h) telophase-II with micronuclei. Bar represents $10 \mu \mathrm{m}(\mathrm{a}=\mathrm{b}, \mathrm{d}=\mathrm{e}-\mathrm{h})$. 


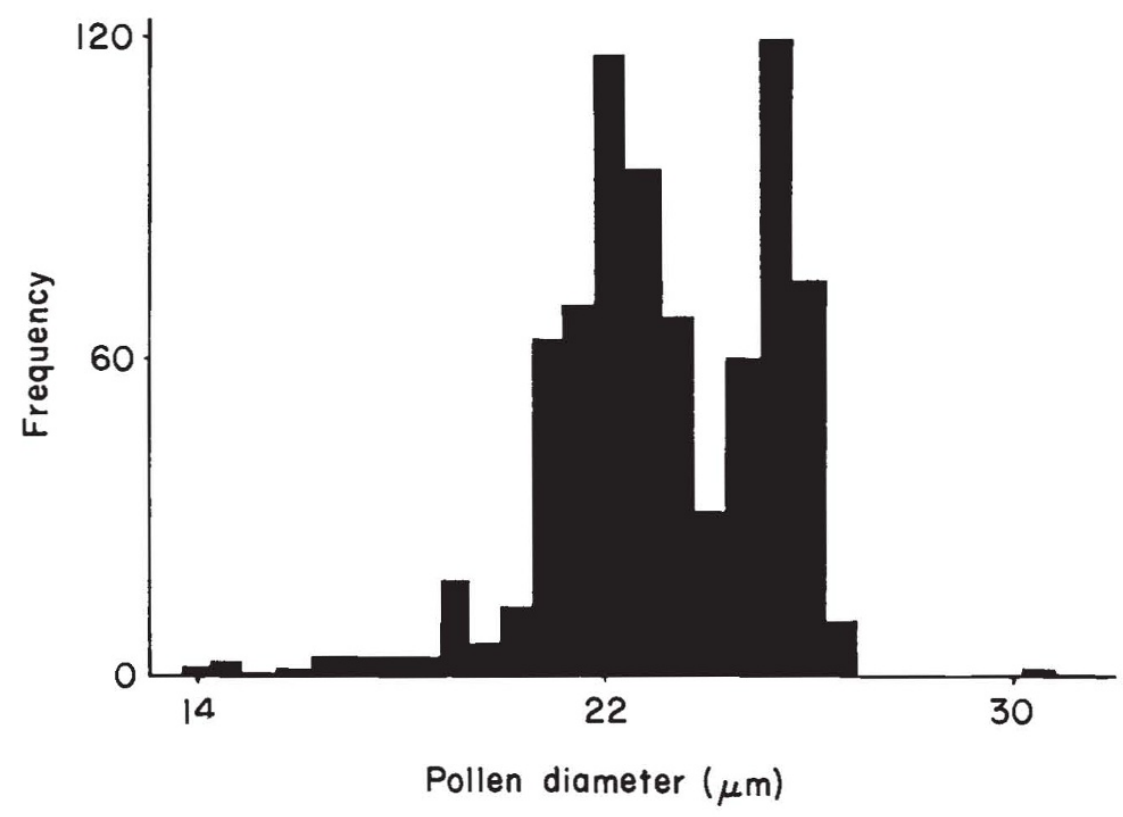

Fig. 7 Variation in pollen grain diameter in Hierochloë odorata from Ravenshall Point.

Table 2 Frequency distributions of micronuclei at telophase in PMCs from a single clone of octaploid Hierochloë odorata, compared with their Poisson expectations (in parentheses)

\begin{tabular}{|c|c|c|c|c|c|c|c|c|c|c|}
\hline \multicolumn{7}{|c|}{ Micronuclei/daughter nucleus } & \multirow{2}{*}{$\begin{array}{l}\text { Total } \\
\text { nuclei }\end{array}$} & \multirow[b]{2}{*}{ Mean } & \multirow[b]{2}{*}{ Variance } & \multirow{2}{*}{$\begin{array}{l}\text { Goodness of fit } \\
\text { to Poisson }\end{array}$} \\
\hline 0 & 1 & 2 & 3 & 4 & 5 & $>5$ & & & & \\
\hline \multicolumn{11}{|c|}{ Telophase-I } \\
\hline 199 & 349 & 252 & 136 & 52 & 22 & 0 & 1010 & 1.563 & 1.481 & $\chi_{\mid 5\}}^{2}=9.358$ \\
\hline$(211.6)$ & $(330.7)$ & $(258.5)$ & $(134.7)$ & $(52.6)$ & $(16.4)$ & $(5.5)$ & & & & $P>0.050$ \\
\hline \multicolumn{11}{|c|}{ Telophase-II } \\
\hline 295 & 402 & 351 & 130 & 51 & $\underbrace{14}$ & 0 & 1243 & 1.422 & 1.310 & $\chi_{[4]}^{2}=12.068$ \\
\hline$(299.7)$ & $(426.3)$ & $(303.2)$ & $(143.8)$ & $(51.1)$ & \multicolumn{2}{|c|}{$\begin{array}{c}14 \\
(19.9)\end{array}$} & & & & $P<0.050$ \\
\hline
\end{tabular}

SDS PAGE showed variation in the seed proteins within families and between populations of Scottish $H$. odorata. In a sample of 16 half-sibs five different banding patterns were observed (Fig. 8a). No variation was observed in the banding patterns of four families of octaploid half-sibs from Sweden (Fig. 8b).

\section{Discussion}

Nuclear restitution is responsible for unreduced gametes and therefore essential to parthenogenesis in the strict sense (Gustaffson, 1946). Although the present study relates only to male meiosis, there is every likelihood that a similar spectrum of meiotic behaviour exists on the female side. In Agropyron scabrum, for example, increases in the frequency of first division restitution in both male and female meiotic cells concord with a rise in the incidence of parthenogenesis (Hair, 1956). Similarly, in Hierochloë itself, male meiosis shows broad correlations with female meiosis across a spectrum of sexual and apomictic species and, a wide range of ploidy (Weimarck, 1973). First division restitution causes diplosporous parthenogenesis in some cases and can even result in the formation of embryo sac-like structures in anthers of some forms of $H$. alpina (Weimarck, 1970a).

The mixture of frequent first and second division restitution in the tetraploid clone of Hierochloë odorata from Ravenshall seems to be very unusual. A similar syndrome is known to be induced in the presence of 

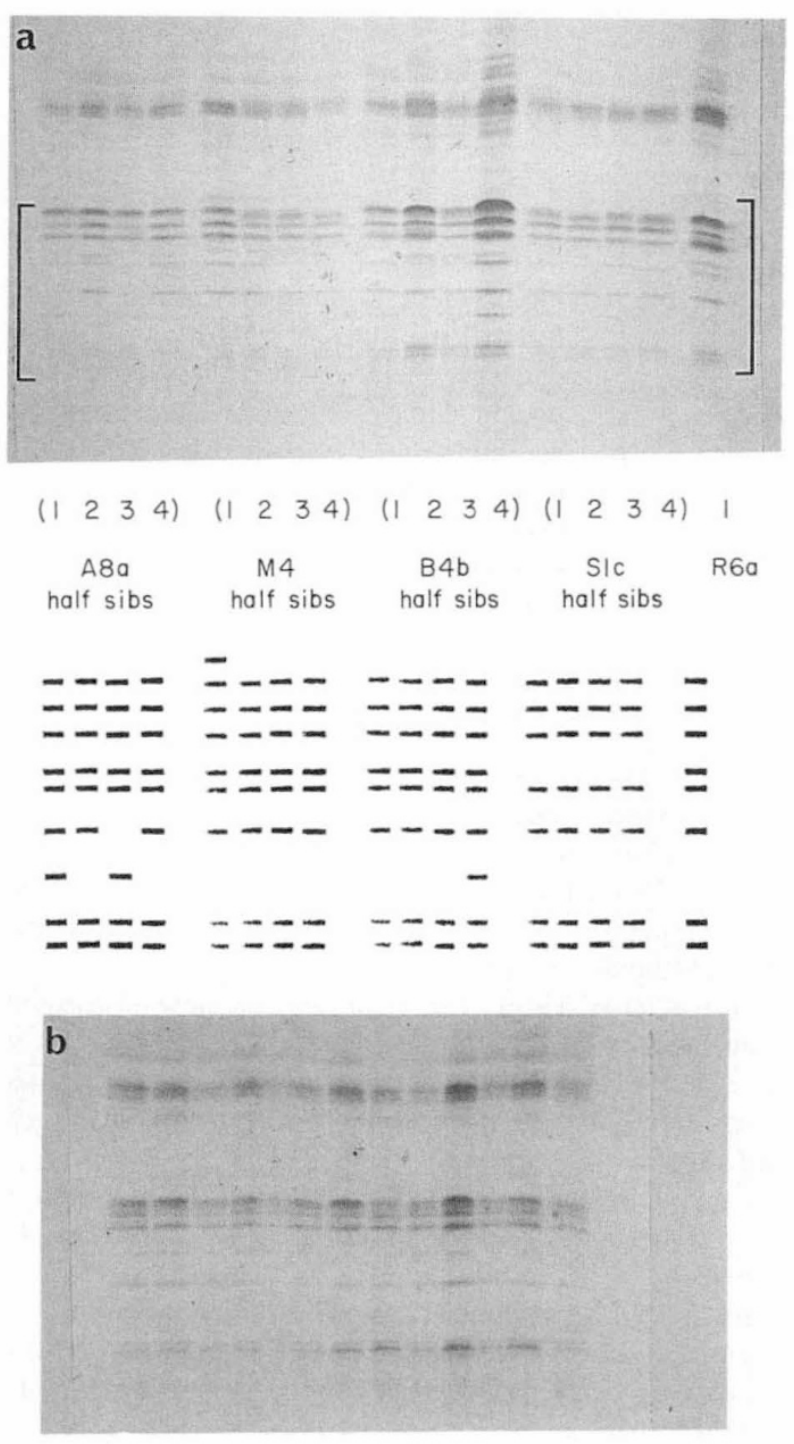

$\left(\begin{array}{lll}1 & 2 & 3\end{array}\right)\left(\begin{array}{lll}1 & 2 & 3\end{array}\right)\left(\begin{array}{lllll}1 & 2 & 3\end{array}\right)\left(\begin{array}{lll}1 & 2 & 3\end{array}\right)$

$\begin{array}{cccc}\text { Ala } & \text { Alb } & A 2 a & A 2 b \\ \text { half sibs } & \text { half sibs } & \text { half sibs } & \text { half sibs }\end{array}$

Fig. 8 SDS polyacrylamide gel electrophoresis of total seed proteins in Hierochloë odorata. (a) Variation within and between four families of Scottish tetraploid half-sibs, idiogram represents bracketed area $\mathrm{A}=$ Alewater, $\mathrm{M}=$ Mary's Knowe, $\mathrm{B}=$ Blackpool Moss, $\mathrm{S}=$ Southwick, $\mathrm{R}=$ Ravenshall Point; (b) uniformity in half-sib families from two octaploid populations at Abisko in Swedish Lapland. $\left(\mathrm{A}_{1}, \mathrm{~A}_{2}\right)$.

high numbers of B-chromosomes in diploid Hypochoeris maculata but the incidences of restitution are not as high as those reported here (Parker et al., 1978). Although asynapsis and extensive non-disjunction are generally known to induce restitution, especially at the first meiotic division (Wagenaar, 1968), there is no evidence that these agents are active in the Ravenshall clone of Hierochloë odorata. The apparent regularity of metaphase pairing in this material and the absence of micronuclei at telophase therefore attest to the failure of anaphase as the primary rather than secondary cause of nuclear doubling. These considerations make it unlikely that restitution has been precipitated by hybridization, as may have occurred in other plant species (Gustaffson, 1936; 1947; Richards, 1973; Cuellar, 1987). Hybridization is thought to be an unlikely cause of parthenogenesis in most invertebrates (Suomaleinen, 1950), with the notable exception of Warramaba virgo (Webb \& White, 1975; Hewitt, 1975 ), but to have played an important role in the evolution of many parthenogenetic vertebrates (Bell, 1982), especially lizards (Cole et al., 1983; Moritz, 1984).

With the exception of the Ravenshall clone, tetraploid $H$. odorata from Scotland appears to be sexual but of low fertility. Univalents and micronuclei are likely to account for the low pollen fertility, while the low seed set may reflect a combination of self-incompatibility and a limited availability of compatible mates. In these respects, Scottish material resembles its tetraploid relatives from Canada and Scandinavia (Weimarck, 1973). By contrast, octaploid plants from Swedish Lapland show much greater meiotic irregularity and are likely to be apomictic. Aposporous octaploids are already known from Sweden (Weimarck, 1967) and from North America (Norstog, 1963).

Because parthenogenetic organisms are not amenable to standard breeding experiments, particularly if obligately non-sexual, their patterns of variation have often been analysed in terms of isozyme mobility on electrophoretic gels (Cuellar, 1987). Such an approach allows clonal uniformity to be tested and levels of heterozygosity to be assessed. In weevils, for example, Saura et al. (1976) have used enzyme studies to support the idea that tetraploid apomicts are monophyletic, while Lokki et al. (1976) have shown that apomictic triploids maintain higher levels of heterozygosity than related sexual diploids. A detailed chromatographic study of species of Hierochlö has proved less diagnostic (Weimarck, 1970b). Although our own evidence does not permit levels of heterozygosity to be compared, it does provide powerful support for sexual reproduction at the tetraploid level but clonal reproduction in octaploids.

The timing of nuclear restitution is well known to influence levels of heterozygosity (John \& Lewis, 1975). Premeiotic restitution, as occurs in Warramaba virgo (White \& Webb, 1968) and many species of worm (Cuellar, 1987), conserves heterozygosity whereas post-meiotic restitution eliminates it. As far as meiotic restitution is concerned, the effects depend 


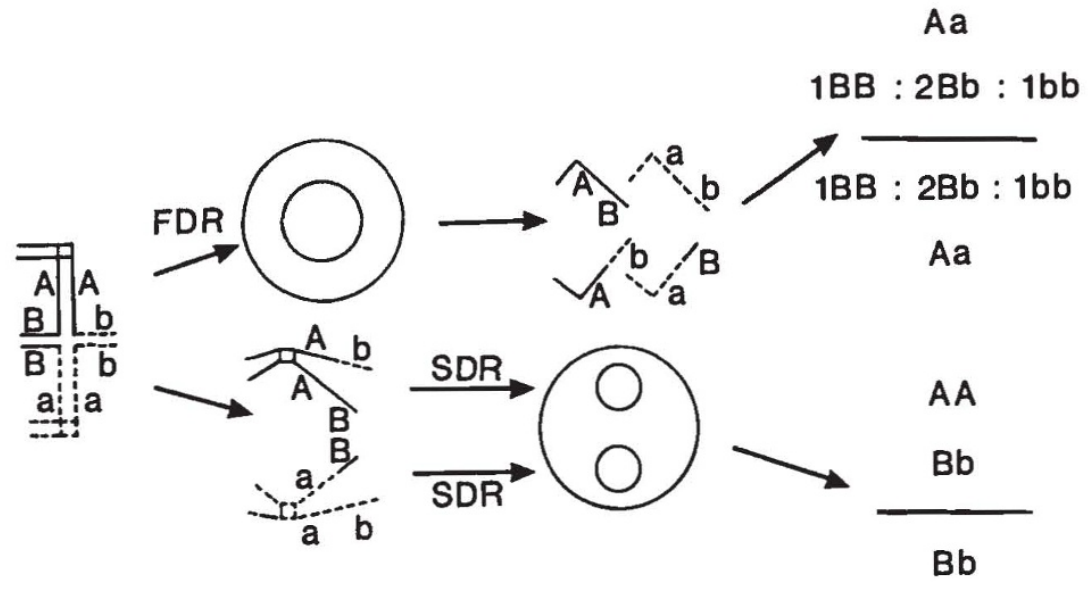

a a
Fig. 9 Genetic effects of meiotic restitution. First division restitution (FDR) conserves heterozygosity in regions proximal to the chiasma while a 50 per cent reduction occurs in distal segments. Second division restitution (SDR) eliminates heterozygosity in regions proximal to the chiasma while heterozygosity in distal regions is conserved. very much on the relative locations of genes and chiasmata (Fig. 9). First division restitution conserves heterozygosity of proximal segments but reduces that of distal segments by a half. This mechanism is by far the most common in flowering plants and is also common in ferns (Cuellar, 1987). It is the only form of parthenogenesis that gives rise to recombinants, however infrequent. Thus the system is deemed subsexual (Darlington, 1939; Hair, 1956). By contrast, consistent failure of the second meiotic division is rare, one of the few cases reported being that of the diploid brine shrimp Artemia salina (Barigozzi, 1944). Interestingly, the triploid inducer gene $(t r i)$ in diploid barley causes second division restitution in about 50 per cent of EMCs but has no effect on PMCs (Finch \& Bennett, 1979). Second division restitution is known to produce less effective unreduced pollen in potato than that which results from failure of the first meiotic division (Mok \& Peloquin, 1975b; Simon \& Peloquin, 1976).

Our own study has shown that first and second division restitutions can occur within a single clone and may indeed even coincide. An experimental study should reveal to what extent the two types of restitution are sensitive to environmental disturbance, as well as their underlying mechanisms.

\section{Acknowledgement}

C. Ferris acknowledges the support of a NERC CASE studentship.

\section{References}

BARIGozzI, C. 1944. I fenomeni cromosomici delle cellule germinale in Artemia salina. Chromosoma, 2, 549-575. BELL, G. 1982. The Masterpiece of Nature, University of California Press, Berkeley, CA.
COLE, C. J., DESSAURER, H. C. \& TOWNSEND, C. R. 1983. Isozymes reveal hybrid origin of neotropical unisexual lizards. Isozyme Bull., 16, 74.

CUELLAR, o. 1987. The evolution of parthenogenesis: a historical perspective. In: Meiosis Moens, P. B. (ed.), Academic Press, Orlando, FL, pp. 43-104.

DARLINGTON, C. D. 1939. The Evolution of Genetic Systems, Oliver \& Boyd, Edinburgh.

DYER, A. F. 1963. The use of lacto-propionic orcein in rapid squash methods of chromosome preparations. Stain Technol., 38, 85-90.

FINCH, R. A. \& BENNETT, M. D. 1979. Action of triploid inducer (tri) on meiosis in barley (Hordeum vulgare). Heredity, 43, 87-93.

FUKUDA, Y. 1927. Cytological studies on the development of the pollen-grain in different races of Solanum tuberosum L., with particular reference to sterility. The Bot. Mag., 41, 459-475.

GUSTAFFSON, A. 1936. Studies on the mechanism of parthenogenesis. Hereditas, 21, 1-112.

gustaffson, A. 1946. Apomixis in higher plants. Part I. The mechanisms of apomixis. Lund. Univ. Arsskr. Avd., 2, [N.S.] 42, 1-72.

gustaffson, A. 1947. Apomixis in higher plants. Part II. The causal aspects of apomixis. Lund. Univ. Arsskr. Avd., 2, [N.S.] 43, 73-182.

HAIR, J. B. 1956. Subsexual reproduction in Agropyron. Heredity, 10, 129-160.

HARLAN, J. R. \& DE WET, J. M. J. 1975. On ö Winge and a prayer: The origins of polyploidy. Bot. Rev., 41, 361-390.

HEwITT, G. M. 1975. A new hypothesis for the origin of the parthenogenetic grasshopper Moraba virgo. Heredity, 34, 117-123.

JOHN, B. \& LEWIS, K. R. 1975. Chromosome Hierarchy. Clarendon Press. Oxford. pp. 117-121.

LOKKI, J., SAURA, A., LANKINEN, P. \& SUOMALEINEN, E. 1976. Genetic polymorphisms and evolution in parthenogenetic animals. VI. Diploid and triploid Polydrosus mollis (Coleoptera: Curculionidae). Hereditas, 82, 209-216.

MCCOY, T. J. 1982. The inheritance of $2 n$ pollen formation in 
diploid Alfalfa Medicago sativa. Can. J. Genet. Cytol., 24, 315-323.

MACEWAn, A. 1986. Ecological Genetics of Poa alpina. Ph.D. Thesis, University of Manchester.

MOK, D. w. S. \& PELOQUIN, S. J. 1975 a. Three mechanisms of $2 n$ pollen formation in diploid potatoes. Can. J. Genet. Cytol., 17, 217-225.

MOK, D. W. S. \& PELOQUIN. S, J. 1975b. The inheritance of three mechanisms of diplandroid ( $2 n$ pollen) formation in diploid potatoes. Heredity, 35, 295-302.

MORITZ, C. 1984. The origin and evolution of parthenogenesis in Heteronotia binoei (Gekkonidae). Chromosoma, 89, 151-162.

MUNTZING, A. 1940. Further studies on apomixis and sexuality in Poa. Hereditas, 26, 115-190.

NORSTOG, K. 1963. Apomixis and polyembryony in Hierochloë odorata. Am. J. Bot., 50, 815-821.

PARKER, J. S., AINSWORTH, C. C. \& TAYLOR, S. 1978. The B-chromosome system of Hypochoeris maculata. II. B-effects on meiotic A-chromosome behaviour. Chromosoma, 67, 123-143.

PARROTT, W. A. \& SMITH, R. R. 1984 . Production of $2 n$ pollen in red clover. Crop Sci. 24, 469-472.

RAMANNA, M. S. 1979. A re-examination of the mechanisms of $2 n$ gamete formation in potato and its implications for breeding. Euphytica, 28, 537-561.

RamanNA, M. S. 1983. First division restitution gametes through fertile desynaptic mutants of potato. Euphytica, 32, 337-350.

RHOADES, M. M. \& DEMPSEY, E. 1966. Induction of chromosome doubling at meiosis by the elongate gene in maize. Genetics, 54, 505-522.

RICHARDS, A. J. 1973. The origin of Taraxacum agamospecies. Bot. J. Linn. Soc., 66, 189-211.

ROSENBERG, O. voN. 1926.. Die Semiheterotypische Teilung and ihre Bedeutung für die Entstehung Verdoppelter Chromosomenzahlen. (English summary). Hereditas, 8, 305-338.

SATINA, S. \& BLAKESLEE, A. F. 1934. Cytological effects of a gene in Datura which causes dyad formation in sporogenesis. Bot. Gaz., 96, 521-532.

SAURA, A., LOKKI, J., LANKINEN, P. \& SUOMALEINEN, E. 1976. Genetic polymorphism and evolution in parthenogenetic animals. II. Tetraploid Otiorhynchus scaber (Coleoptera: Curculinidae). Hereditas, 82, 79-100.

SIMON, P. W. \& PELOQUIN, S. J. 1976. Pollen vigour as a function of mode of $2 n$ gamete formation in potatoes. J. Hered., 67, 204-208.
STERN, H. 1946. The formation of polynucleated pollen mother cells, in Trillium erectum J. Hered., 37, 47-50.

SUOMAleinen, E. 1950. Parthenogenesis in animals. Adv. Genet., 3, 193-253.

TEOH, S. B. 1984. Polyploid spore formation in diploid orchid species. Genetica, 63, 53-59.

VEILLEUX, R. E., MCHALE, N. A. \& LAUER, F. I. 1982. $2 n$ gametes in diploid Solanum: Frequency and types of spindle abnormalities. Can. J. Genet. Cyto.. 24, 301-314.

WAGENAAR, E. B. 1968. Meiotic restitution and the origin of polyploidy II. Prolonged duration of metaphase I as causal factor of restitution induction. Can. J. Genet. Cyto. 10, 844-852.

WEBB, G. C. \& WHITE, M. J. D. 1975 . Heterochromatin and timing of DNA replication in morabine grasshoppers. In: The Eukaryotic Chromosome, Peacock, W. J. \& Brock, R. D. (eds) Australian National University Press, Canberra, pp. 395-408.

weImarCK, G. 1967. Apomixis and sexuality in Hierochloë australis and in Swedish $H$. odorata on different ploidy levels. Bot. Notiser., 120, 209-235.

weimarck, G. 1970a. Apomixis and sexuality in Hierochlö alpina (Gramineae) from Finland and Greenland and in H. monticola from Greenland. Bot. Notiser., 123, 495-504.

WEIMARCK, G. 1970b. Spontaneous and induced variations in some chemical leaf constituents in Hierochloë (Gramineae). Bot. Notiser., 123, 231-268.

WEIMARCK, G. 1971. Variation and taxonomy of Hierochloë (Gramineae) in the northern hemisphere. Bot. Notiser., 124, 129-175.

WIEMARCK, G. 1973. Male meiosis in some amphimictic and apomictic Hierochloë (Gramineae). Bot. Notiser., 126, 7-36.

WEIMARCK, G. 1976. Karyotypes and population structure in aneuploid Hierochloë alpina ssp alpina (Gramineae) in northern Scandinavia. Hereditas, 82, 149-155.

WHITE, M. J. D. 1970. Heterozygosity and genetic polymorphism in parthenogenetic animals. In: Essays in Evolution and Genetics in Honor of Theodusius Dobzhansky, Hecht, M. K. and Steere, W. C. (eds) North-Holland Publications, Amsterdam, pp. 237-262.

WHITE, M. J. D. \& WEBB, G. C. 1968 . Origin and evolution of parthenogenetic reproduction in the grasshopper Moraba virgo (Emasticidae: Morabinae). Aust. J. Zool., 16, 647-671. 